\title{
CD8+ Cell Anti-HIV Activity Correlates with the Clinical State of the Infected Individual
}

Cart E. Mackewicz, Henry W. Ortega, and Jay A. Levy

Department of Medicine, Cancer Research Institute, University of California School of Medicine, San Francisco, California $94143-0128$

\begin{abstract}
The extent of antiviral activity exhibited in vitro by CD8 + lymphocytes from individuals infected by HIV-1 correlates significantly with their clinical status. CD8+ lymphocytes from asymptomatic subjects were found to inhibit HIV-1 replication by $90 \%$ or greater at effector/target $(E / T)$ ratios ranging from as low as 0.05 to 0.25 . CD8 + cells from 17 of $19(89 \%)$ of these subjects suppressed replication at an $E / T$ ratio of 0.10 or less. CD8+ lymphocytes from symptomatic patients (non-AIDS) inhibited HIV-1 replication at $E / T$ ratios ranging from 0.05 to 1.0 , and CD8 + cells from 8 of $13(62 \%)$ required ratios $>0.10$. As a group, patients with AIDS exhibited the lowest degree of anti-HIV activity with their CD8 + lymphocytes. The effective range of $E / T$ ratios from AIDS patients was 0.10-2.0, and 9 of $10(90 \%)$ required $E / T$ ratios $>0.25$. This anti-HIV activity exhibited by CD8 + cells also correlated significantly with the subject's peripheral blood CD4+ cell count. The relative extent of CD8 + cell anti-HIV-1 activity was not found dependent on variations in the CD4+ target cells and viruses used. These findings suggest that the decreased CD8 + cell antiviral activity is related to progression to disease in HIV-infected individuals. (J. Clin. Invest. 1991. 87:1462-1466.) Key words: AIDS • HIV-1 infected cells • CD4+ cell number • cell-mediated immunity $\bullet$ CD8 + cells • peripheral blood mononuclear cells
\end{abstract}

\section{Introduction}

In animal models of virus infection, cellular immune functions have been shown to be important for controlling the virus by eliminating virus-infected cells (1-5). In HIV-1 infection, cellular effector functions such as antibody-dependent cellular cytotoxicity $(6-8)$, NK cell killing $(9,10)$, and cytotoxic T lymphocyte (CTL) ${ }^{1}$ activity (11-14) have been demonstrated, but it is still uncertain whether cellular immunity plays a role in

Address correspondence and reprint requests to Dr. Jay A. Levy, Department of Medicine, Cancer Research Institute, University of California School of Medicine, San Francisco, CA 94143-0128.

Received for publication 31 August 1990 and in revised form 6 November 1990.

1. Abbreviations used in this paper: ARC, AIDS-related complex; CTL, cytoxic T lymphocyte; E/T, effector/target; IM, immunomagnetic; RT, reverse transcriptase.

J. Clin. Invest.

(c) The American Society for Clinical Investigation, Inc. $0021-9738 / 91 / 04 / 1462 / 05 \$ 2.00$

Volume 87, April 1991, 1462-1466 protecting the host. HLA-restricted anti-HIV cytotoxic $\mathrm{T}$ cells (CD8+ or CD4+) have been found in individuals at early as well as late stages of HIV-1 infection (12), and some studies demonstrate a reduction in CTL response with progression to disease $(14,15)$. This latter observation, therefore, suggests that these CTL might help control HIV infection in the host.

CD8+ lymphocytes from infected individuals have also been observed to inhibit HIV replication in naturally infected CD4+ $T$ cells in vitro (16-19). This type of antiviral activity is not mediated by CD16+/CD8+ (NK) cells, is not HLA-restricted, can be demonstrated with low numbers of CD8+ cells, and is dose dependent. Moreover, the activity does not involve cell killing, and appears to be mediated in part through a soluble factor $(16,18,20,21)$.

To determine if this anti-HIV response by $\mathrm{CD} 8+$ cells serves a protective function in the host, its relation to clinical status was examined. The extent of CD8+ cell antiviral activity in HIV-1-infected individuals was evaluated and then compared with their clinical state and their absolute CD4+ lymphocyte count.

\section{Methods}

Subjects. HIV-1 seropositive subjects from three clinical categories were evaluated in this study: clinically healthy individuals, symptomatic non-AIDS patients (referred to in this report as AIDS-related complex [ARC]), and individuals with AIDS as defined by the Centers for Disease Control criteria consisting of Kaposi's sarcoma and Pneumocystis carinii pneumonia. The ARC patients presented with symptoms of either oral candidiasis, hairy leukoplakia, persistant lymphadenopathy, idiopathic thrombocytopenia purpura, herpes zoster, cerebrospinal fluid pleocytosis, or combinations thereof. Some of the subjects evaluated in this study are participants in the San Francisco Mens Health Study and their blood samples were kindly provided by Dr. Warren Winkelstein, Berkeley, CA.

Isolation of effector and target cells. The PBMC were obtained from heparinized blood by Ficoll-Hypaque gradient separation (22). Naturally infected CD4+ target cells and CD8+ effector cells were sequentially isolated from each subject using anti-CD4 or anti-CD8 coated immunomagnetic (IM) beads (Dynabeads M-450; Dynal, Oslo, Norway). 20-50 million PBMC were resuspended in 4-5 ml cold $\left(\sim 4^{\circ} \mathrm{C}\right)$ PBS containing $2 \%$ heat-inactivated $\left(30 \mathrm{~min}, 56^{\circ} \mathrm{C}\right)$ FCS (Irvine Scientific, Santa Ana, CA). This single-cell suspension was added to antiCD4 IM beads which had been previously washed three times with cold PBS containing 2\% FCS (PBS-2\% FBS) to yield a bead to target cell ratio of $\sim 3: 1$. The bead-cell suspension was incubated at $4^{\circ} \mathrm{C}$ on a rotating-rocking machine for 30-45 min. Cells rossetted with IM beads were captured by placing the tube in a magnetic device (Dynal magnetic particle concentrator) for 1-2 min followed by removal of the supernatant containing the nonbound cells. The rossetted cells were washed three times with cold PBS-2\% FBS using the magnetic capture device as described and then enumerated. 
The nonadherent (CD4-depleted) cells were treated with washed anti-CD8 IM beads (again at a 3:1 ratio of beads to estimated target cell number) and the above procedure repeated. In each case, cell recovery was from 50-85\% of the number of estimated target cells, and purity of both CD4+ and CD8 + cell populations was $95 \%$ or greater as assessed by flow cytometric analyses. Double-staining studies on activation markers expressed by CD4+ or CD8 + cells before and after isolation by IM beads showed no difference in percentage of CD25, CD38, and HLA-DR expressed by either $T$ cell subpopulation.

Flow cytometric analysis. T cell subset purity was analyzed by a double-staining procedure (23) on a Becton-Dickinson FACScan ${ }^{\oplus}$ using anti-Leu3a FITC and anti-Leu2a PE, kindly provided by BectonDickinson Corp., Mountain View, CA.

Assay for CD8+ cell anti-HIV activity. Freshly isolated naturally infected CD4+ target cells $\left(6-8 \times 10^{5}\right)$ were cultured alone or in the presence of freshly isolated autologous CD8+ effector cells at the following CD8:CD4 ratios: $0.05,0.10,0.25,0.50,1.0$, and 2.0. The cells were grown in RPMI 1640 medium containing $2 \mathrm{mM}$ glutamine, $1 \%$ antibiotics ( $100 \mathrm{U} / \mathrm{ml}$ penicillin; $100 \mu \mathrm{g} / \mathrm{ml}$ streptomycin), $10 \%$ heat-inactivated $\left(56^{\circ} \mathrm{C}, 30 \mathrm{~min}\right.$.) FCS, and $200 \mathrm{U} / \mathrm{ml}$ human recombinant IL-2 (DuPont Co., Wilmington, DE). Cells were cultured in 24-well plates (1.2 ml total volume) in the presence of PHA (Sigma Chemical Co., St. Louis, $\mathrm{MO})(3 \mu \mathrm{g} / \mathrm{ml})$ at $37^{\circ} \mathrm{C}$ in a humidified $5 \% \mathrm{CO}_{2}$ incubator. After $3 \mathrm{~d}$ in culture, the PHA-containing medium was removed and the cells were resuspended in fresh RPMI 1640 medium (with recombinant IL2 but no PHA) and moderately pipetted to free any IM beads still bound to cells. The resultant cell suspensions were transferred to tubes and placed in the magnetic capture device to remove the detached IM beads. The IM bead-free cells were then transferred to a new well.

Cell cultures were subsequently passed every $3 \mathrm{~d}$ for at least $15 \mathrm{~d}$, and the supernatants were monitored for reverse transcriptase (RT) activity as described (24). The amount of RT activity was compared with that of the CD4+ cells cultured alone and the percentage reduction of peak RT activity calculated. As a reference cut off point for antiviral activity, $90 \%$ reduction of peak RT activity was chosen. Thus, the extent of anti-HIV activity exhibited by a given subject's CD8+ lymphocytes is reflected by the lowest CD8/CD4 ratio at which a $90 \%$ or greater reduction of peak RT activity was observed. The stringent 90\% reduction reference point, rather than a lower percentage value, was chosen because it best distinguished the relative differences in the degree of CD8 + cell antiviral activity among the various subjects studied.

This assay of CD8 + cell antiviral activity using IM beads gave comparable results to those previously conducted using a panning technique (16). In the acute infection assay described below, the effector cells were obtained by positive selection (using IM beads) of CD8+ lymphocytes from the subject's PBMC which previously had been stimulated in the presence of PHA for $3 \mathrm{~d}$.

Preparation of acutely infected CD4+ cell targets. IM bead-purified CD4+ cells were obtained from seronegative blood samples (provided by Irwin Memorial Blood Bank, San Francisco, CA), then stimulated with PHA ( $3 \mu \mathrm{g} / \mathrm{ml})$ for $3 \mathrm{~d}$ at $37^{\circ} \mathrm{C}$ in the RPMI 1640 culture medium described above containing $10 \%$ purified human IL-2 (Electronucleonics, Inc., Silver Spring, MD). The IM beads were then removed and the CD4+ lymphocytes washed twice with HBSS. 3-10 million CD4+ lymphocytes were resuspended in culture medium containing polybrene (Sigma Chemical Co.) $(2 \mu \mathrm{g} / \mathrm{ml})$ and incubated at $37^{\circ} \mathrm{C}$ for onehalf hour. Cells were subsequently spun down to remove the polybrene medium and resuspended in $1 \mathrm{ml}$ of culture supernatant containing $10,000 \mathrm{TCID}_{50}$ of HIV-1 $\mathrm{SF33}$. The cells were incubated with virus for 90 min at $37^{\circ} \mathrm{C}$ after which they were washed twice with HBSS to remove unbound viral particles. This method of acute infection routinely yields $10-15 \%$ antigen-positive cells as measured by an indirect immunofluorescent assay (25) at peak replication (5-7 d).

Statistical analysis. Statistical evaluations were carried out using the nonparametric Spearman Rank Correlation Coefficient analysis (26) calculated from the experimental data using the computer software program StatView SE+ Graphics (Brain Power, Inc., Calabasas, CA 91302).

\section{Results}

The extent of CD8+ cell anti-HIV activity correlates with clinical status and CD4+ cell number. The relative degree of CD8+ cell anti-HIV-1 activity was assessed in 19 asymptomatic, 13 symptomatic (ARC), and 10 AIDS patients, and is reflected by the effector/target (E/T) ratio required to inhibit $\mathrm{RT}$ activity by $>90 \%$ (Fig. $1 \mathrm{~A}$ ). The ranges of $\mathrm{E} / \mathrm{T}$ ratios that gave suppression of HIV-1 replication in autologous infected CD4+ cells from the asymptomatic, ARC, and AIDS subjects were 0.05$0.25,0.05-1.0$, and $0.10-2.0$, respectively. These numbers reflect some overlap in the relative anti-HIV activity exhibited by CD8+ lymphocytes from these three clinical groups, but the data indicate a significant correlation between the relative degree of anti-HIV activity and clinical status (Spearman rank coefficient $\mathrm{Rho}=0.789, P=0.0001$ ). Strong antiviral response was associated with an absence of clinical symptoms. CD8+ cells from 17 of $19(89 \%)$ of the asymptomatic individuals in-

A)

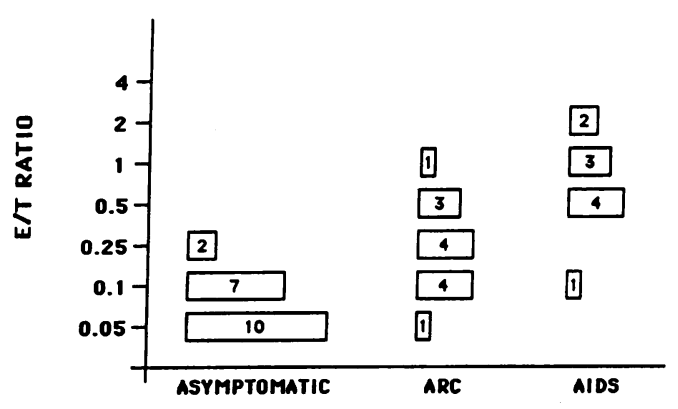

DIAGNOSIS

B)

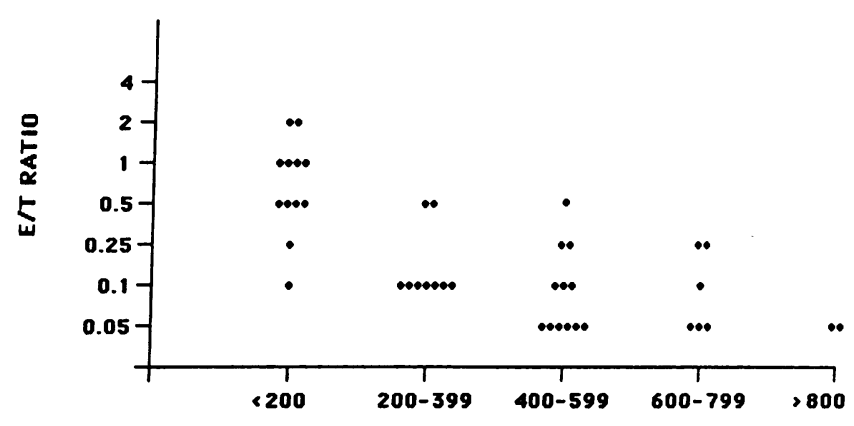

$\mathrm{CO}^{+}$LYMPHOCYTES / $\mu \mathrm{I}$

Figure 1. Extent of CD8+ cell anti-HIV-1 activity exhibited by a population of subjects at various stages post HIV-1 infection. AntiHIV-1 activity from each subject's CD8 + cells was titrated over a range of $E / T$ ratios $(0.05-2.0)$ against naturally infected autologous CD4+ target cells. The extent of antiviral activity exhibited (represented by the lowest $\mathrm{E} / \mathrm{T}$ ratio yielding $\geq 90 \%$ reduction of $\mathrm{RT}$ activity) was compared with the subject's clinical diagnosis $(A)$, and to their respective number of $\mathrm{CD} 4+$ cells/ $\mu$ l grouped within the indicated range $(B)$. Numbers shown in the boxes $(A)$ represent the number of individuals whose CD8+ cells inhibit HIV-1 replication at the indicated ratio. 
hibited HIV-1 replication at an E/T ratio of 0.10 or less and 10 of $17(59 \%)$ were able to suppress virus release at a $0.05 \mathrm{E} / \mathrm{T}$ ratio. Analysis of $\mathrm{CD} 8+$ cells from $\mathrm{ARC}$ patients revealed that $31 \%$ ( 4 of 13 ), $31 \%$ ( 4 of 13 ), and $23 \%$ ( 3 of 13 ) suppressed the virus at $\mathrm{E} / \mathrm{T}$ ratios of $0.10,0.25$, and 0.50 , respectively. One individual with $\mathrm{ARC}$ required as little as one effector CD8+ cell per every $20 \mathrm{CD} 4+$ cells $(0.05 \mathrm{E} / \mathrm{T}$ ratio) while one other needed more than one effector cell per every two CD4+ cells (>0.5 E/T ratio). In contrast, CD8+ lymphocytes from most AIDS patients ( 9 of 10 or $90 \%$ ) controlled virus replication at a $0.50 \mathrm{E} / \mathrm{T}$ ratio or greater. Two of the AIDS patients required an $\mathrm{E} / \mathrm{T}$ ratio of 2.0 .

The relative extent of CD8+ cell anti-HIV-1 activity also correlated significantly with the absolute number of peripheral blood CD4+ cells in each subject (Spearman rank coefficient Rho $=0.682, P=0.0001$ ) (Fig. $1 B$ ). CD8+ lymphocytes from individuals with less than $400 \mathrm{CD} 4+$ cells/ $\mu$ l were unable to inhibit HIV-1 replication at the $0.05 \mathrm{E} / \mathrm{T}$ ratio, and CD8+ cell effectors from 10 of 12 (83\%) of those with $200 \mathrm{CD} 4+$ cells/ $\mu \mathrm{l}$ were unable to control replication at a $0.25 \mathrm{E} / \mathrm{T}$ ratio. In contrast, $>50 \%$ (11 of 20) of the individuals with more than 600 CD4+ cells/ $\mu$ l exhibited CD8+ cell anti-HIV control at the $0.05 \mathrm{E} / \mathrm{T}$ ratio.

When five individuals (four asymptomatic and one AIDS) were evaluated for anti-HIV activity on return visits over a period of time (up to $15 \mathrm{mo}$ in one case), little or no change in the number of CD8+ lymphocytes required to inhibit HIV-1 replication was observed (Fig. 2). In each case the subject's clinical state remained unchanged and their CD4+ cell counts fluctuated by less than $\pm 90 / \mu l$ (data not shown). These results indicate that the extent of CD8 + cells anti-HIV-1 activity can be stable for many months.

The relative extent of $C D 8+$ cell anti-HIV activity is not dependent on the HIV-1 strain. To determine whether the relative ability of an individual's CD8 + cells to inhibit HIV replication in their autologous naturally infected CD4+ cells was dependent on the target cell or characteristics of the virus, two types of experiments were performed. First, CD8+ lymphocytes from selected HIV-infected individuals were evaluated for their relative antiviral activity against naturally infected CD4+ cells from other individuals suspected to have different virus loads. The results indicated similar levels of CD8+ cell antiviral activity with the CD4+ cell targets used (Fig. 3). These

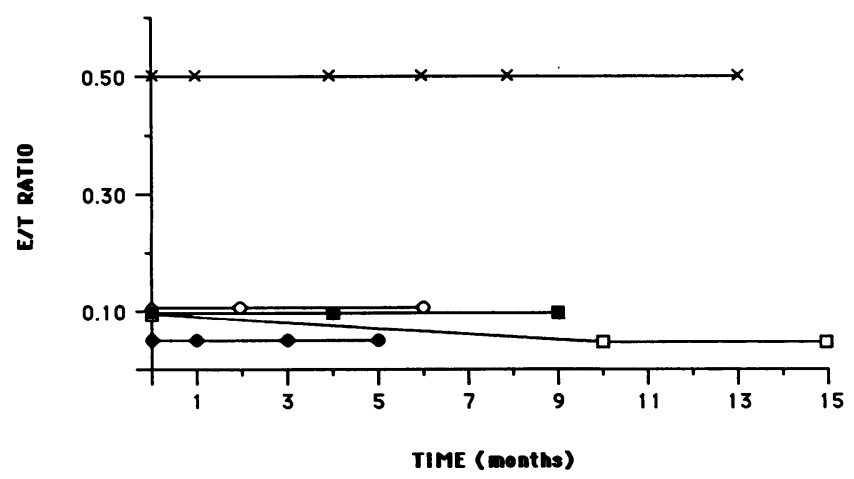

Figure 2. Extent of CD8+ cell anti-HIV-1 activity exhibited by five different subjects over time. The clinical state of each subject remained unchanged over the period of time indicated. Four subjects were asymptomatic and one had Karposi's sarcoma $(-\times-)$.
A)

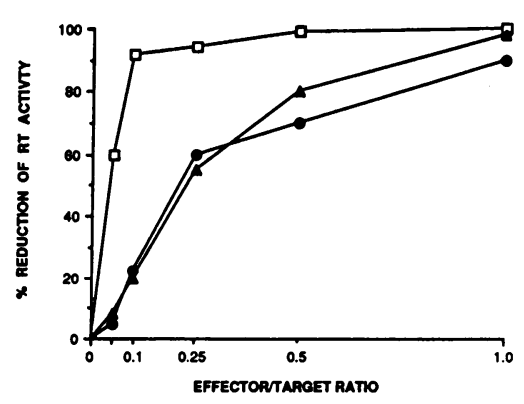

B)

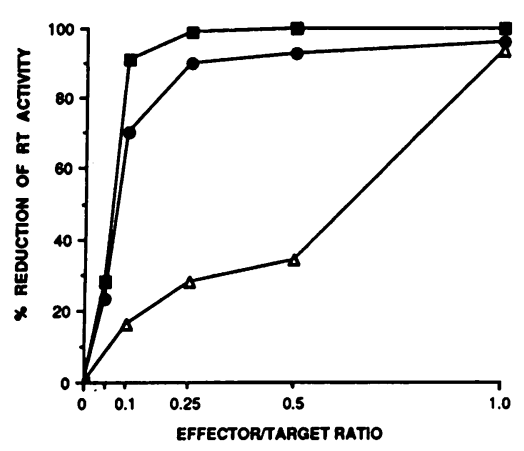

C)

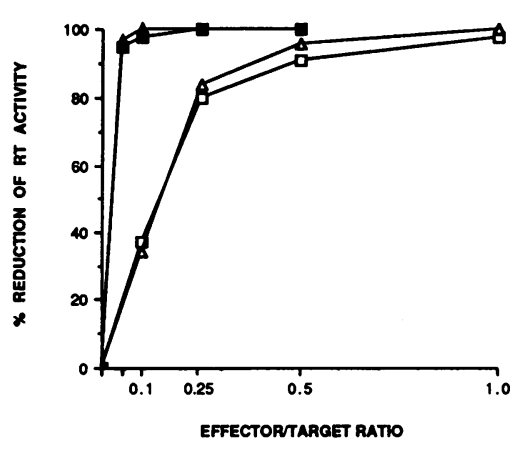

Figure 3. CD8+ cell anti-HIV-1 activity against different infected CD4+ target cells. (A) CD8+ lymphocytes from an HIV infected subject (No. 2) who exhibits efficient antiviral activity only at high $\mathrm{E} / \mathrm{T}$ ratios titrated against his own CD4+ cells (- - -), and those from another infected subject (No. 1) (一- -) who exhibits antiviral activity at low $\mathrm{E} / \mathrm{T}$ ratios when titrated against his own CD4+ cells (- -$)$. (B) CD8+ lymphocytes from an infected subject (No. 4) who exhibits antiviral activity at low $\mathrm{E} / \mathrm{T}$ ratios titrated against his own CD4+ cells (- - -), and those from a subject (No. 3) (- - -) who exhibits antiviral activity only at high $\mathrm{E} / \mathrm{T}$ ratios when titrated against his own CD4+ cells $(-\Delta-)$. (C) $\mathrm{CD} 8+$ cells from two other infected individuals were separately titrated against each other's CD4+ cells. Subject 5's CD8+ cells against subject 5's CD4+ cells (- - -) or subject 6's CD4+ cells (- -$)$. Subject 6's CD4+ cells against subject 6's CD4+ cells (口-) or subject 5's CD4+ cells $(-\Delta-)$.

experiments were possible because the particular CD8+ cell anti-HIV function under study does not require HLA compatibility with the target CD4+ cells to inhibit HIV-1 replication (16).

In the first experiment (Fig. $3 \mathrm{~A}$ ), the results showed that the CD8 + cells of subject 1 inhibited HIV-1 replication in autologous targets by $>90 \%$ at the E/T ratio of 0.05 . Subject 2's CD8+ cells, however, inhibited HIV-1 replication in autologous targets by $92 \%$ only at the highest $\mathrm{E} / \mathrm{T}$ ratio tested, 1.0. When subject 2's CD8+ cells are titrated against subject 1's CD4+ targets (hence, subject 1's virus and virus load), the resultant titration curve closely parallels that seen when these CD8 + cells are titrated against autologous (subject 2) targets.

In the converse experiment (Fig. $3 \mathrm{~B}$ ) analogous results were obtained. Subject 4's CD8+ lymphocytes were able to control HIV-1 replication in subject 3's CD4 + targets to a similar extent as they controlled virus replication in the autologous CD4+ targets. Moreover, when the analogous comparison was 
performed in a third experiment (Fig. $3 C$ ) assaying the relative extent of CD8 + cell anti-viral activity from an AIDS patient (subject 6) and an asymptomatic subject (subject 5) against both subjects' CD4+ cells, the results confirmed that the degree of CD8+ cell anti-HIV-1 activity is not dependent on which CD4+ cell targets are used.

The second approach considered the possible influence of the CD4+ cell, the number of infected cells, or the virus strain on the results. It involved measuring the CD8+ cell anti-HIV activity using acutely infected CD4+ lymphocytes from H IV-1 seronegative donors as the target cell population. The infected subjects' CD8+ lymphocytes were the effector cells. Results with seven subjects analyzed with this acute infection assay system are summarized in Fig. 4. In each case the anti-HIV-1 activity measured in the acute infection assay indicated a requirement for 2-5 times more CD8+ effector cells compared with the number needed to suppress virus in the "naturally infected" (endogenous) assay. Most importantly, however, individuals whose $\mathrm{CD} 8+$ cells exhibit control at low $\mathrm{E} / \mathrm{T}$ ratios against autologous naturally infected CD4+ targets also inhibited virus at comparably low $\mathrm{E} / \mathrm{T}$ ratios in the acute infection assay. Thus, subjects $A-D$ who control at $E / T$ ratios $0.10,0.05$, 0.05 , and 0.10 , respectively, in the endogenous assay suppress at $0.5,0.10,0.25$, and $0.25 \mathrm{E} / \mathrm{T}$ ratios, respectively, in the acute infection assay. In contrast, subjects $E, F$, and $G$, who each exhibit anti-HIV control at a $0.50 \mathrm{E} / \mathrm{T}$ ratio in the endogenous assay, required $\mathrm{E} / \mathrm{T}$ ratios of $2.0,4.0$, and 2.0 , respectively, in the acute infection assay.

\section{Discussion}

The potential clinical relevance of the antiviral activity exhibited by CD8+ lymphocytes (16) from HIV-1 seropositive individuals was investigated. The results indicate that the degree of CD8 + cell anti-HIV-1 activity correlates significantly with a subject's clinical state and with the number of peripheral blood CD4+ cells present. Asymptomatic individuals exhibit the highest amount of CD8+ anti-HIV activity, followed by ARC patients, and then AIDS patients who showed the least antiHIV activity (Fig. $1 \mathrm{~A}$ ). In general, most AIDS patients required 5-10 times the number of effector CD8+ cells to suppress HIV-1 replication than did asymptomatic individuals; some needed as many as $\mathbf{2 0 - 4 0}$ times more. In addition, CD8+ cells from several asymptomatic subjects, when mixed with

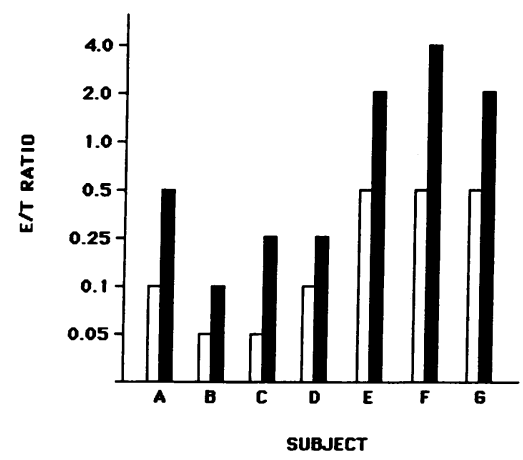

Figure 4. Extent of CD8+ cell anti-HIV-1 activity as measured by the endogenous virus and the acute virus infection assays. Open bars ( $\square$ ) represent results obtained when antiHIV-1 activity by the subject's CD8+ cells was titrated against autologous naturally infected CD4+ cells (endogenous virus assay).

Dark bars ( $₫$ ) represent results obtained when the CD8+ lymphocytes from the same individual were titrated against CD4+ lymphocytes acutely infected with $\mathrm{HIV}-1_{\text {SF33 }}$ (acute virus infection assay).
$\mathrm{CD} 4+$ targets at the $\mathrm{E} / \mathrm{T}$ ratio of 0.05 , inhibited $\mathrm{RT}$ activity by $97 \%$ or greater (data not shown). This finding indicates that they most likely could suppress HIV-1 replication at even lower E/T ratios. This relative extent of CD8+ cell anti-HIV activity was stable over a period of time in individuals whose clinical state did not change (Fig. 2). Since this anti-HIV-1 activity reflects the clinical state, and the absolute number of CD4+ cells decreases as an infected individual progresses from an asymptomatic state to disease (27), the correlation of CD8+ cell anti-HIV activity with CD4+ cell counts was not unexpected (Fig. $1 \mathrm{~B}$ ).

To evaluate further why most symptomatic individuals (ARC and AIDS subjects) exhibited diminished anti-HIV activity with their CD8+ cells, we examined the influence of the CD4+ cell target and the virus. Previous work in our laboratory, for example, had shown that individuals who progress to disease have a rapidly replicating HIV-1 strain that grows to high titer in culture (28). The results of two different approaches indicated no effect of variations of the CD4+ cell target, virus load, or virus strain on the CD8+ cell response. A subject's CD8+ lymphocytes maintained a similar level of antiHIV control whether their activity was titrated against naturally infected CD4+ targets from a subject with good anti-HIV control or one with poor anti-HIV control (Fig. 3). Moreover, comparable results were obtained with the endogenous virus assay system and the acute infection assay (Fig. 4) in which a highly cytopathic HIV-1 strain was used. Since, in the latter study the same target CD4+ lymphocytes were acutely infected with the same stock of virus under identical conditions, the potential variability due to different CD4+ cells, HIV-1 variants, or the number of infected target cells was avoided. The difference in magnitude of anti-HIV activity needed to control HIV-1 replication in the acute versus the endogenous assay may reflect an increased number of infected CD4+ cell targets in the acute system, or a different mechanism needed to inhibit HIV-1 replication from a proviral state versus acute virus infection.

The diminished levels of anti-HIV activity could result from either a defect in CD8+ cell function or the selective loss of a particular CD8+ subpopulation(s) (29). The latter may involve a lack of CD4+ T cell help often found in HIV-1-infected individuals who have progressed to disease $(30,31)$ and is supported by the lower numbers of CD4+ cells observed. Alternatively, the decrease in antiviral activity exhibited by ARC and AIDS patients could be a consequence of reduced mitogen responsiveness by their lymphocytes (32). These possibilities are under study.

In any case, the findings suggest that decreasing CD8+ cell anti-HIV activity plays a role in progression to disease by not controlling HIV replication in vivo. The observations could explain the relatively low virus loads found in healthy individuals as compared to AIDS patients (33). A major objective now is to determine the underlying cause(s) of the deterioration of CD8+ cell function in HIV-infected individuals.

\section{Acknowledgments}

Christine Beglinger and Yvonne Young are thanked for their help in preparation of the manuscript.

These studies were supported by National Institutes of Health grants NO1-AI-82515 and AI-24286. 


\section{References}

1. Yap, K. L., G. L. Ada, and I. F. C. McKenzie. 1978. Transfer of specific cytotoxic T lymphocytes protects mice inoculated with influenza virus. Nature (Lond.). 273:238-239.

2. Leclerc, J. C., and H. Cantor. 1980. T cell mediated immunity to oncornavirus-induced tumors. II. Ability of different $\mathrm{T}$ cell sets to prevent tumor growth in vivo. J. Immunol. 124:851-854.

3. Engers, H. D., T. La Haye, G. D. Sorensen, A. L. Glasebrook, C. Horvath, and K. T. Brunner. 1984. Functional activity in vivo of effector T cell populations. II. Anti-tumor activity exhibited by syngereic anti-MoMuLV-specific cytolytic T cell clones. J. Immunol. 133:1664-1670.

4. Quinnan, G. V., N. Kirmeni, A. H. Rook, J. F. Manische, L. Jackson, G. Moreschi, G. W. Santos, R. Saral, and W. H. Burns. 1982. Cytotoxic T cells in cytomegalovirus infection: HLA-restricted T-lymphocyte and non-T lymphocyte cytotoxic responses correlate with recovery from cytomegalovirus infection in bone-marrow-transplant recipients. $N$. Engl. J. Med. 307:6-13.

5. McMichael, A. J., F. M. Gotch, G. R. Noble, and P. A. S. Beave. 1983. Cytotoxic T cell immunity to influenza. N. Engl. J. Med. 309:13-17.

6. Ojo-Amaize, E. A., P. Nishanian, D. E. Keith, Jr., R. L. Houghton, D. F. Heitjan, J. L. Fahey, and J. V. Giorgi. 1987. Antibodies to human immunodeficiency virus in human sera induce cell-mediated lysis of human immunodeficiency virus-infected cells. J. Immunol. 139:2458-2463.

7. Shepp, D. H., S. Chakrabarti, B. Moss, and G. V. Quinnan, Jr. 1988. Antibody-dependent cellular cytotoxicity specific for the envelope antigens of human immunodeficiency virus. J. Infect. Dis. 157:1260-1264.

8. Evans, L. A., G. Thomson-Honnebier, K. M. Steimer, E. Paoletti, M. E. Perkus, H. Hollander, and J. A. Levy. 1989. Antibody-dependent cellular cytotoxicity is directed against both the gp 120 and gp41 envelope proteins of HIV. AIDS. 3:273-276.

9. Creemers, P., D. Stark, and W. Boyko. 1985. Evaluation of natural killer cell activity in patients with persistent generalized lymphadenopathy and acquired immunodeficiency syndrome. Clin. Immunol. Immunopathol. 36:141148.

10. Bonavida, B., J. Katz, and M. Gottlieb. 1986. Mechanism of defective NK cell activity in patients with acquired immunodeficiency syndrome (AIDS) and AIDS-related complex. I. Defective trigger on NK cells for NKCF production by target cells and partial restoration by IL-2. J. Immunol. 137:1157-1160.

11. Plata, F., B. Autran, L. P. Martins, S. Wain-Hobson, M. Raphael, C. Mayaud, M. Denis, J. M. Guillon, and P. Debre. 1987. AIDS virus-specific cytotoxic T lymphocytes in lung disorders. Nature (Lond.). 328:348-351.

12. Walker, B. D., S. Chakrabarti, B. Moss, T. J. Paradis, T. Flynn, A. G. Durna, R. D. Blumberg, J. C. Kaplan, M. S. Hirsch, and R. T. Schooley. 1987. HIV-specific cytotoxic T lymphocytes in seropositive individuals. Nature (Lond.). 328:345-348.

13. Nixon, D. F., A. R. M. Townsend, J. G. Elvin, C. R. Rizza, J. Gallwey, and A. J. McMichael. 1988. HIV-1 gag-specific cytotoxic T lymphocytes defined with recombinant vaccinia virus and synthetic peptides. Nature (Lond.). 336:484-486.

14. Hoffenbach, A., P. Langlade-Demoyen, G. Dadaglio, E. Vilmer, F. Michel, C. Mayaud, B. Autran, and F. Plata. 1989. Unusually high frequencies of HIV-specific cytotoxic T lymphocytes in humans. J. Immunol. 142:452-462.

15. Guillon, J. M., B. Autran, M. Denis, P. Fouret, F. Plata, C. M. Mayaud, and J. M. Akoun. 1988. HIV-related lymphocytic alveolitis. Chest. 94:12641270.

16. Walker, C. M., D. J. Moody, D. P. Stites, and J. A. Levy. 1986. CD8+ lymphocytes can control HIV infection in vitro by suppressing virus replication. Science (Wash. DC). 234:1563-1566.

17. Kannagi, M., L. V. Chalifoux, C. I. Lord, and N. L. Letvin. 1988. Suppression of simian immunodeficiency virus replication in vitro by CD8+ lymphocytes. J. Immunol. 140:2237-2242.

18. Walker, C. M., D. J. Moody, D. P. Stites, and J. A. Levy. 1989. CD8+ T lymphocyte control of HIV replication in cultured CD4+ cells varies among infected individuals. Cell. Immunol. 119:470-475.

19. Brinchmann, J. E., G. Gaudernack, and F. Vartdal. 1990. CD8+ T cells inhibit HIV replication in naturally infected CD4+ T cells. J. Immunol. 144:2961-2966.

20. Wiviott, L. D., C. M. Walker, and J. A. Levy. 1990. CD8+ lymphocytes suppress HIV production by autologous CD4+ cells without eliminating the infected cells from culture. Cell. Immunol. 128:628-634.

21. Walker, C. M., and J. A. Levy. 1989. A diffusible lymphokine produced by CD8+ T lymphocytes suppresses HIV replication. Immunology. 66:628-630.

22. Levy, J. A., and J. Shimabukuro. 1985. Recovery of AIDS-associated retroviruses from patients with AIDS or AIDS-related conditions and from clinically healthy individuals. J. Infect. Dis. 152:734-738.

23. Levy, J. A., L. H. Tobler, T. M. McHugh, C. H. Casavant, and D. P. Stites. 1985. Long-term cultivation of $T$ cell subsets from patients with acquired immune deficiency syndrome. Clin. Immunol. Immunopathol. 35:328-336.

24. Hoffman, A. D., B. Banapour, and J. A. Levy. 1985. Characterization of the AIDS-associated retrovirus reverse transcriptase and optimal conditions for its detection in virions. Virology. 147:326-335.

25. Kaminsky, L. S., T. McHugh, D. Stites, P. Volberding, G. Henle, W. Henle, and J. A. Levy. 1985. High prevalence of antibodies to AIDS-associated retroviruses (ARV) in acquired immune deficiency syndrome and related conditions and not in other disease states. Proc. Natl. Acad. Sci. USA. 82:5535-5539.

26. Hollander, M., and D. Wolfe. 1973. Nonparametric statistical methods. John Wiley \& Sons, Inc., New York.

27. Lang, W., H. Perkins, R. E. Anderson, R. Royce, N. Jewell, and W. Winkelstein, Jr. 1989. Patterns of T lymphocyte changes with human immunodeficiency virus infection: from seroconversion to the development of AIDS. $J$. Acquired Immune Defic. Synd. 2:63-69.

28. Cheng-Mayer, C., D. Seto, M. Tateno, and J. A. Levy. 1988. Biologic features of HIV that correlate with virulence in the host. Science (Wash. DC). 240:80-82.

29. Giorgi, J. V., and R. Detels. 1989. T-cell subset alterations in HIV-infected homosexual men: NIAID multicenter AIDS cohort study. Clin. Immunol. Immunopathol. 52:10-18.

30. Rosenberg, Z. F., and A. S. Fauci. 1989. The immunopathogenesis of HIV infection. Adv. Immunol. 47:377-431.

31. Gluckman, J. C., D. Klatzman, M. Carvaille-Coll, E. Porisson, A. Messiah, D. Lachiver, and W. Rozenbaum. 1985. Is there a correlation of T cel proliferative functions and surface membrane phenotypes in patients with acquired immune deficiency syndrome or lymphadenopathy syndrome? Clin. Exp. Immunol. 60:8-14.

32. Gurley, R. J., K. Ikeuchi, R. A. Byrn, K. Anderson, and J. E. Groopman. 1989. CD4+ lymphocyte function with early human immunodeficiency virus infection. Proc. Natl. Acad. Sci. USA. 86:1993-1997.

33. Ho, D. D., T. Moudgil, and M. Alam. 1989. Quantitation of human immunodeficiency virus type 1 in the blood of infected persons. N. Engl. J. Med. 321:1621-1625. 